ROZ D Z I A E 3 .

\title{
ZMIANY WYBRANYCH ELEMENTÓW KULTURY EKONOMICZNEJ MIESZKAŃCÓW OBSZARÓW WIEJSKICH W POLSCE
} Magdalena Owczarczuk ${ }^{1}$

\section{Wstęp}

Nieodłącznymi elementami społeczeństwa są jego kultura, tradycje, zwyczaje i wartości. Mimo to, wpływ kultury, czy szerzej - czynników pozaekonomicznych na rozwój gospodarczy, nie był i nie jest przedmiotem badań głównego nurtu ekonomii. Znaczący impuls do rozwoju nowych szkół w naukach ekonomicznych, dali ekonomiści z amerykańskiego nurtu, określanego mianem instytucjonalizmu: Thorstein B. Veblen (1857-1929), Wesley C. Mitchell (1874-1948), John R. Commons (1862-1945). Thorstein B. Veblen stwierdził m.in., że ekonomia powinna badać zmianę struktur instytucjonalnych, które akceptowane w danym czasie, wynikają głównie z nawyków myślowych. Według niego charakter instytucji wypływa ze zwyczajów będących efektem ciągłej asymilacji przyzwyczajeń, dokonywanej na drodze selektywnej adaptacji rozwiązań, które są najbardziej korzystne z punktu widzenia danej społeczności. W ten sposób, co zauważa również Profesor Adam Sadowski, instytucje kulturowe, które w ekonomii

${ }^{1}$ Dr Magdalena Owczarczuk, Uniwersytet w Białymstoku. 
ortodoksyjnej były traktowane jako ceteris paribus systemu, trafiły do ekonomii i za sprawą Veblena zaczęto je analizować².

Kultura ekonomiczna stanowi część szeroko rozumianej kultury, dorobek społeczeństwa wytworzony w rozwoju historycznym. Wpływa istotnie na otoczenie, w którym zachodzą procesy ekonomiczne (produkcja, wymiana, konsumpcja), na normy, zachowania się ludzi i jakość stosunków międzyludzkich w organizacjach oraz na warunki rozwijania wiedzy w procesach ekonomicznych, a więc także na rozwój kapitału ludzkiego na potrzeby gospodarki ${ }^{3}$. Kultura ekonomiczna odgrywa rolę jednej z postaci instytucji nieformalnych, które pełnią funkcję społecznego zakorzenienia.

Rozwój obszarów wiejskich uwzględniający różne jego ścieżki, bardzo istotnie oddziałuje na kulturę ekonomiczną mieszkańców wsi. Celem niniejszego rozdziału jest ukazanie występujących w sferze kultury ekonomicznej mieszkańców obszarów wiejskich, przeobrażeń i ich kierunku. Wielofunkcyjność wsi i pojawienie się na obszarach wiejskich nowych podmiotów gospodarczych i społecznych wpływa na przeobrażenia w strukturze społecznej, przejścia od znacznej homogeniczności zbiorowości wiejskich do ich pogłębiającego się zróżnicowania. Istnieje wiele elementów kultury ekonomicznej istotnej dla dalszego rozwoju obszarów wiejskich, w tym m.in. gotowość do zdobywania wiedzy, przedsiębiorczość, skłonność do ryzyka, zdolność do kooperacji i inne.

\subsection{Kultura ekonomiczna jako instytucja nieformalna}

Pojęcie instytucji jest szeroko rozumiane i używane we wszystkich naukach społecznych ${ }^{4}$. Z socjologicznego punktu widzenia instytucje są

${ }^{2}$ A. Sadowski, Własność a użytkowanie gruntów rolnych. Zarys tendencji rozwojowych, Wydawnictwo Uniwersytetu w Białymstoku, Białystok 2009, s. 28.

${ }^{3}$ G. Krzymieniewska, Kultura ekonomiczna mieszkańców obszarów wiejskich. Problemy - Przekształcenia - Wyzwania, Wydawnictwo Adam Marszałek, Toruń 2013, s. 32.

${ }^{4}$ A. Sadowski, dz. cyt.., s. 34. 
tym, dzięki czemu dokonuje się przystosowanie niespołecznego z natury człowieka do współdziałania z innymi ludźmi, jest to więc zazwyczaj trwały stosunek społeczny. W naukach prawnych instytucje utożsamiane są z jednostkami organizacyjnymi lub zespołem norm regulujących stosunki społeczne. Na gruncie nauk ekonomicznych ukształtowało się wiele definicji instytucji. Współczesne badania instytucjonalne najczęściej sięgają do definicji zaproponowanej przez Douglassa C. Northa. Pod pojęciem instytucji nowa ekonomia instytucjonalna rozumie „zasady gry”, co formalnie można określić jako wszelkie ograniczenia, które stworzyli ludzie, aby kształtować interakcje zachodzące między nimi ${ }^{5}$. Ich bezpośrednim celem jest ograniczenie niepewności podczas podejmowania działań bądź decyzji. Instytucje wzmacniają wspomniane reguły, narzucając określony sposób zachowań, co prowadzi w rezultacie do możliwych do przewidzenia zasad postępowania.

Instytucje tworzą podstawę każdej cywilizacji. Normy społeczne i religijne są źródłem wielu przepisów prawnych. Te z kolei określają reguły, zasady współżycia i współdziałania obowiązujące wszystkich członków społeczeństwa. Aby normy te były przestrzegane wymagają sankcji społeczeństwa. Normy prawne różnią się od społecznych i religijnych tym, że są ustanowione i skodyfikowane formalnie, a władza i instytucje państwa zapewniają ich przestrzeganie ${ }^{6}$.

Instytucje nieformalne obok instytucji formalnych stanowią element systemu instytucjonalnego danego społeczeństwa. Zasób norm nieformalnych, do których zaliczyć możemy: tradycję, zwyczaje, wartości moralne, wierzenia religijne i inne pojawiały się w sposób często spontaniczny jako efekt rozwoju społeczeństw i w wielu przypadkach przetrwały próby czasu. W miarę rozwoju niektóre z tych norm przybierały postać norm formalnych, jednakże znaczna ich część nadal pozostaje w sferze niesformalizowanej,

${ }^{5}$ D.C. North, Institutions, Institutional Change and Economic Performance, The Cambridge University Press, Cambridge 2009, s. 3-4, 68.

${ }^{6}$ J.W. Bossak, Instytucje, rynki i konkurencja we współczesnym świecie, SGH, Warszawa 2008, s. 24. 
co nie oznacza, jak pisze Profesor Sadowski, że ich moc jest mało znacząca. Poparte są one systemem sankcji, wśród których możemy wyróżnić wykluczenie ze społeczności, utratę reputacji, napiętnowanie, ostracyzm. W związku z tym są one mocno zakorzenione w społeczeństwach ${ }^{7}$.

Instytucje nieformalne są najbardziej trwałym elementem systemu instytucjonalnego, gdyż ich ewolucja wiąże się ze zmianą mentalności, która jest głęboko zakorzeniona w kulturze danego społeczeństwa. Jednak, co zauważa prof. J. Wilkin „...trwałość niektórych instytucji, mierzona stuleciami, nie musi stanowić przeszkody w dostosowywaniu się jednostek i społeczeństw do zmieniających się warunków. Kultura jest przejawem plastyczności natury ludzkiej, a różnorodność kultur obrazem bogactwa

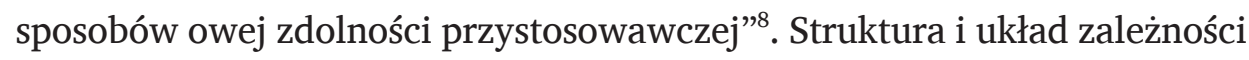
między układem instytucjonalnym a poszczególnymi instytucjami tworzą system ekonomiczny, polityczny i społeczny. Podejście instytucjonalne przełamuje bariery oddzielające system ekonomiczny od innych systemów społecznych. Zachowania ludzi w sferze gospodarowania, życia społecznego czy politycznego mogą być determinowane przez te same elementy systemu instytucjonalnego (tradycje, religię i inne) ${ }^{9}$.

Kultura ekonomiczna jest częścią szeroko rozumianej, historycznie ukształtowanej kultury. Dotyczy uznanych i pożądanych przez daną społeczność norm, wartości, wiedzy, wzorów postępowania odnoszących się do procesów gospodarowania. Określa cele i metody postępowania w obszarze aktywności gospodarczej, warunki w jakich cele i metody ich realizacji mogą zyskać akceptację społeczną, kryteria, według których można kształtować i poddawać ocenie politykę ekonomiczną ${ }^{10}$.

${ }^{7}$ A. Sadowski, Nowa ekonomia instytucjonalna jako próba poszerzenia możliwości analitycznych ekonomii neoklasycznej w stosunku do własności i użytkowania ziemi, „Rocznik Stowarzyszenia Naukowców Polaków Litwy” 2008/2009, t. 7/8, s. 116.

8 J. Wilkin, Instytucjonalne i kulturowe podstawy gospodarowania. Humanistyczna perspektywa ekonomii, Wydawnictwo Naukowe Scholar, Warszawa 2016, s. 88.

${ }^{9}$ Tamże, s. 105.

${ }^{10}$ G. Krzymieniewska, dz. cyt.., s. 73. 
Kulturę ekonomiczną wyznacza zintegrowany system czynników przesądzający o zachowaniach jednostki w obszarze gospodarki. Wśród składników kultury ekonomicznej, decydujących o jej kształcie, można wymienić $^{11}$ :

- socjalizację ekonomiczną;

- posiadaną przez jednostkę i zbiorowość wiedzę ekonomiczną;

- umiejętności niezbędne do poruszania się w gospodarce rynkowej (w tym m.in. umiejętność zdobywania informacji, współpracy, rozwiązywania problemów, planowania działań, stosowania nowych rozwiązań i inne);

- stosunek do pieniędzy i oszczędzania;

- stosunek do pracy;

- przedsiębiorczość i stosunek do przedsiębiorczości;

- poziom aspiracji materialnych;

- konsumpcję.

Kultura ekonomiczna, definiowana jako sposób myślenia i działania jednostek oraz społeczności w sferze gospodarki, może być więc uznana za czynnik rozwoju gospodarczego, gdyż obejmuje swym pojęciem szereg ważnych zmiennych. Czynniki te mogą przesądzać o potencjalnych możliwościach danej populacji w uczestniczeniu w procesach gospodarczych i w ostatecznym rozrachunku posiadania przewagi konkurencyjnej danej zbiorowości i społeczeństwa jako całości ${ }^{12}$.

Kultura ekonomiczna jest również kategorią badawczą. Badania kultury ekonomicznej mogą się odbywać na kilku poziomach ${ }^{13}$. Poziom makroekonomiczny występuje, gdy analizy kultury ekonomicznej odnoszone są do danego społeczeństwa, gdzie ich przedmiotem badania są ukształtowane

\footnotetext{
11 Tamże, s. 40.

${ }^{12}$ G. Krzymieniewska, Rozwój kultury ekonomicznej w warunkach zróżnicowania regionalnego obszarów wiejskich, "Journal of Agribusiness and Rural Development", 2014, nr 1(31), s. 83.

13 Tejże, Kultura ekonomiczna..., s. 39.
} 
historyczne wartości kulturowe społeczeństwa określające sposób myślenia o gospodarce. To one wpływają na wyobrażenia jednostek na temat etosu pracy, stosunek do zróżnicowania materialnego, konsumpcję i inne. Poziom mezoekonomiczny badań - występuje, gdy analiza kultury ekonomicznej dotyczy poszczególnych grup społecznych i zawodowych. Pozwala to na określenie różnic zachodzących między poszczególnymi kategoriami społecznymi. Za jej pomocą można wyjaśnić obszary zagrożeń społecznych związanych z możliwością wykluczenia, dysproporcji rozwojowych między środowiskami prowadzącymi do usztywnienia struktury społecznej, konfliktów, jakie mogą powstać między pracodawcą a pracownikiem i inne. Mikroekonomiczny poziom analiz pozwala na badanie kultury organizacyjnej przez wzory i wartości typowe dla danej organizacji lub przez analizę intensywności specyficznych zachowań o dużej doniosłości społecznej (kolektywizm/indywidualizm; kobiecość/męskość; orientacja długoterminowa/ orientacja krótkoterminowa i inne).

\subsection{Przemiany roli i funkcji obszarów wiejskich}

Obszary wiejskie pełnią dwie ogólne funkcje: produkcyjną i konsumpcyjną. Pierwsza funkcja związana jest ze zlokalizowaniem w przestrzeniach wiejskich zakładów wytwórczych, produkujących w pierwszym rzędzie żywność (nieprzetworzoną i coraz częściej przetworzoną), ale także inne dobra. Druga natomiast wiąże się z istnieniem ośrodków aktywności innego rodzaju, związanych z rekreacją, wypoczynkiem, ochroną krajobrazu, a także pełnieniem funkcji rezydencjalnych ${ }^{14}$. Przystąpienie Polski do Unii Europejskiej spowodowało dynamiczne zmiany w polskim rolnictwie. Dotyczą one zwłaszcza poszczególnych funkcji obszarów wiejskich.

${ }^{14}$ H. Podedworna, Przemiany zbiorowości wiejskich, [w:] Współczesne społeczeństwo polskie. Dynamika zmian, J. Wasilewski (red.), Wydawnictwo Naukowe Scholar, Warszawa 2006, s. 227. 
Możemy zauważyć, iż współczesne dyskusje wokół funkcji rolnictwa i obszarów wiejskich w gospodarce, przypisują im wiele rozmaitych ról, dalece wykraczających poza tradycyjnie rozumiane produkowanie żywności. Wyraźnie zwiększa się różnorodność działalności gospodarczej realizowanej na obszarach wiejskich, przy dużym przestrzennym zróżnicowaniu tych funkcji. Tak zwana wielofunkcyjność obszarów wiejskich rozpatrywana w kontekście ich rozwoju jest następstwem zgodności wielofunkcyjnego rozwoju gospodarstwa, rolnictwa i obszarów wiejskich jako całości w powiązaniu z koncepcją zrównoważonego rozwoju kraju ${ }^{15}$. Wielofunkcyjność jest ideą aktywizacji wsi i dywersyfikacji działalności gospodarczej, zgodnie z którą przyszłość ludności wiejskiej jest związana nie tylko z rolnictwem, ale także z innymi działami gospodarki. Dzięki niej dokonują się przekształcenia i różnicowanie źródeł dochodów mieszkańców wsi ${ }^{16}$. Z kolei koncepcja zrównoważonego rozwoju w odniesieniu do obszarów wiejskich zakłada jednoczesne dążenie do poprawy warunków życia ludności i prowadzenia działalności gospodarczej na tych obszarach, przy nienaruszaniu przy tym specyficznych zasobów wsi takich jak środowisko naturalne, krajobraz wsi i dziedzictwo kulturowe. W ujęciu praktycznym istotą rolnictwa zrównoważonego jest równoczesna i harmonijna realizacja celów produkcyjnych, ekonomicznych, ekologicznych i społecznych ${ }^{17}$.

Zmiany w rolnictwie oraz rozwój obszarów wiejskich nie mogą następować w oderwaniu od ogólnej sytuacji społeczno-gospodarczej, zwłaszcza stanu jego otoczenia i zaawansowania społeczno-kulturowego ludności na określonym terenie. Dlatego też wśród uwarunkowań zmian funkcji obszarów wiejskich można wymienić te o charakterze makroekonomicznym (globalizacja, liberalizacja handlu, wzrost międzynarodowej konkurencyjności,

\footnotetext{
${ }^{15}$ E. Niedzielski, Funkcje obszarów wiejskich i ich rozwój, „Zagadnienia Ekonomiki Rolnej” 2015, nr 2 (343), s. 89.

${ }^{16}$ G. Krzymieniewska, Kultura ekonomiczna..., s. 97-104.

${ }^{17}$ D. Żmija, Zrównoważony rozwój rolnictwa i obszarów wiejskich w Polsce, „Studia Ekonomiczne" 2014, nr 166, s. 150-151.
} 
zmiany technologiczne), cywilizacyjno-kulturowym (zmiany warunków życia, zmiany wartości i celów realizowanych w życiu) czy też mikroekonomicznym (rozwój infrastruktury, wyposażenie techniczne, środki pomocowe i dofinansowania ze środków Unii Europejskiej) ${ }^{18}$.

Do nowych funkcji obszarów wiejskich można zaliczyćc ${ }^{19}$ :

- pozarolnicze funkcje produkcyjne, polegające na podejmowaniu działalności uzupełniającej i wykorzystującej nisze rynkowe, np. szansę tworzy wykorzystanie produkcji energetycznej, artystycznej, przetwórstwa przydomowego, usług, działań turystycznych i agroturystycznych;

- funkcje ekologiczne, polegające na utrzymaniu przyrodniczych podstaw życia, ochronie ginących gatunków, dbałości o stan lokalnych zasobów przyrodniczych;

- funkcje rezydencjalne, polegające na oferowaniu bezpiecznej i atrakcyjnej przestrzeni mieszkalnej, w kontakcie z przyrodą, wolnej od uciążliwości życia w wielkim mieście; te walory przestrzeni wiejskiej doceniają głównie osoby starsze, których rytm życia jest nieco wolniejszy, ale także rodziny z dziećmi traktując tereny wiejskie w zasięgu oddziaływania wielkich aglomeracji miejskich jako miejsce lokalizacji tzw. sypialni miejskich;

- funkcje społeczno-kulturowe, obejmujące m.in. ochronę kultury lokalnej, tradycyjnego krajobrazu wiejskiego, pozostałości wiejskiej kultury materialnej, tradycyjnej działalności gospodarczej, rzemiosł i inne;

- funkcje rekreacyjne, obejmujące wytwarzanie i ochronę przestrzeni służącej aktywności wypoczynkowej, rekreacyjnej, regeneracji zdrowia $\mathrm{i}$ inne.

${ }^{18}$ Szerzej o uwarunkowaniach rozwoju rolnictwa m.in. w: Ekonomia jest piękna. Księga dedykowana profesorowi Jerzemu Wilkinowi, Ł. Hardt, D. Milczarek-Andrzejewska (red.), Wydawnictwo Naukowe Scholar, Warszawa 2015.

${ }^{19}$ H. Podedworna, dz. cyt., s. 227-228; B. Klepacki, Uwarunkowania rozwoju rolnictwa oraz obszarów wiejskich $w$ ujęciu historycznym i wspótczesnym, [w:] Ekonomia jest piękna? Księga dedykowana profesorowi Jerzemu Wilkinowi, s. 404; E. Niedzielski, Funkcje obszarów wiejskich i ich rozwój, „Zagadnienia Ekonomiki Rolnej” 2015, nr 2(343), s. 92. 


\subsection{Zmiany wybranych elementów kultury ekonomicznej}

Pojawienie się na terenach wiejskich nowych funkcji, podjęcie działalności pozarolniczej stawia przed mieszkańcami wsi zupełnie nowe wyzwania. Przede wszystkim jest to związane z koniecznością zdobycia i rozszerzenia nowych kompetencji zawodowych i społecznych. Oznacza poszerzenie wiedzy z różnych dziedzin - rachunkowości, finansów czy zarządzania, ale także zmiany w postawach i myśleniu: porzucanie postaw biernych i zachowawczych, a przyjmowanie aktywnych i przedsiębiorczych. W wielofunkcyjnym rozwoju kultura ekonomiczna mieszkańców wsi ulega znacznemu poszerzeniu, włączając nowe doświadczenia do posiadanych kompetencji. Osoby, które podejmują na wsi działalność gospodarczą (rolniczą czy pozarolniczą) powinny mieć świadomość istniejącego ryzyka, przejawiać gotowość do współpracy (w tym z innymi przedsiębiorcami lub interesariuszami zewnętrznymi), gotowość do przedsiębiorczych zachowań i znajomość praw uczestnictwa w grze rynkowej.

Mimo wielu kontrowersji wokół określenia cech prorozwojowej kultury ekonomicznej, nie ulega wątpliwości, iż kapitał społeczny, jako część kultury, jest znaczącym źródłem rozwoju społecznego i gospodarczego ${ }^{20}$. W naukach społecznych powszechnie przyjmuje się pogląd, że fundamentalne znaczenie dla procesu budowania kapitału społecznego (społeczeństwa obywatelskiego) mają dwie postawy: akceptacja normy zachęcającej do wspólnotowego działania oraz zdolność do ufania innym ${ }^{21}$.

Działalność zespołowa w rolnictwie umożliwia osiągnięcie wielu celów, w tym m.in.: ${ }^{22}$

${ }^{20}$ F. Fukuyama, Zaufanie. Kapitat społeczny a droga do dobrobytu, WarszawaWrocław 1997, s. 56.

${ }^{21}$ Polska wieś 2018. Raport o stanie wsi, J. Wilkin, I. Nurzyńska (red.), Wydawnictwo Naukowe Scholar, Warszawa, s. 79.

22 B. Klepacki, dz. cyt., s. 399. 
- obniżanie jednostkowych kosztów wytwarzania, a dzięki temu uzyskanie korzystniejszej pozycji konkurencyjnej wobec innych producentów;

- uzyskanie wyższych cen zbytu, dzięki, z jednej strony, lepszemu rozpoznaniu potrzeb odbiorców i przygotowaniu towaru pożądanej jakości, a z drugiej - z tytułu większej partii wystandaryzowanego towaru do handlu lub przerobu;

- lepsza promocja produktów ze względu na możliwość przeprowadzenia profesjonalnej reklamy, jak i pozyskanie rozmaitych znaków o charakterze jakościowym czy wyróżniającym (np. produkt regionalny);

- podnoszenie jakości technologii i produktu;

- uzyskanie dodatkowego wsparcia finansowego w ramach Programu Rozwoju Obszarów Wiejskich 2014-2020, Działanie 9. Tworzenie grup producentów i organizacji producentów.

Badania pokazują, że norma akceptująca wspólnotowe działania z innymi ludźmi jest bliska poglądom wszystkich Polaków, mieszkańców wsi i miast. Ogólny wskaźnik gotowości do współpracy z ludźmi spoza własnej rodziny, mierzony na skali od 0 do $4(0=$ niechęć do współdziałania we wszystkich czterech dziedzinach; 4 = gotowość do współpracy we wszystkich dziedzinach ${ }^{23}$ ), w 2018 roku dla ogółu Polaków wyniósł 1,86, podczas gdy dla mieszkańców wsi wyniósł $1,76^{24}$. Zapewne pozytywnym zjawiskiem jest wzrost tego wskaźnika. W 2010 roku dla mieszkańców wsi wynosił on $1,69^{25}$. Należy dodać, że w porównaniu z 2016 rokiem znacząco wzrósł (o 7 p.p.) odsetek rolników przekonanych, że działając wspólnie $\mathrm{z}$ innymi osiągnie się więcej niż samemu ${ }^{26}$. Pozytywne zmiany na wsi

${ }^{23}$ Gotowość do współpracy została oceniona w czterech dziedzinach: polityki, biznesu, kształtowania lokalnego środowiska i budowania relacji międzyludzkich. Uwzględniono gotowość do wspólnego prowadzenia działalności gospodarczej i politycznej, pracy społecznej na rzecz swojego środowiska i osób potrzebujących oraz pożyczenia wartościowych rzeczy.

${ }^{24}$ Gotowość Polaków do współpracy, Komunikat z badań CBOS nr 30/2018, s. 6.

25 Gotowość Polaków do wspótpracy, Komunikat z badań CBOS nr BS/32/2010

${ }^{26}$ Polska wieś 2018. Raport o stanie wsi..., s. 79. 
można dostrzec również w bardziej szczegółowej analizie tego wskaźnika. Okazuje się, że wzrasta gotowość do współpracy w sferze biznesu, mimo iż poziom tej zmiennej plasuje się na niskim poziomie (w 2016 roku na wsi jedynie 37\% respondentów uznało „że zna osobę spoza swojej rodziny, z którą gotów byłby wspólnie prowadzić działalność gospodarczą" - wykres 3.1.). Może to świadczyć o wzroście świadomości i wiedzy, w tym wiedzy ekonomicznej mieszkańców wsi.

Wykres 3.1. Odsetek osób gotowych do współpracy w poszczególnych dziedzinach (w \%) w 2016 i 2012 roku

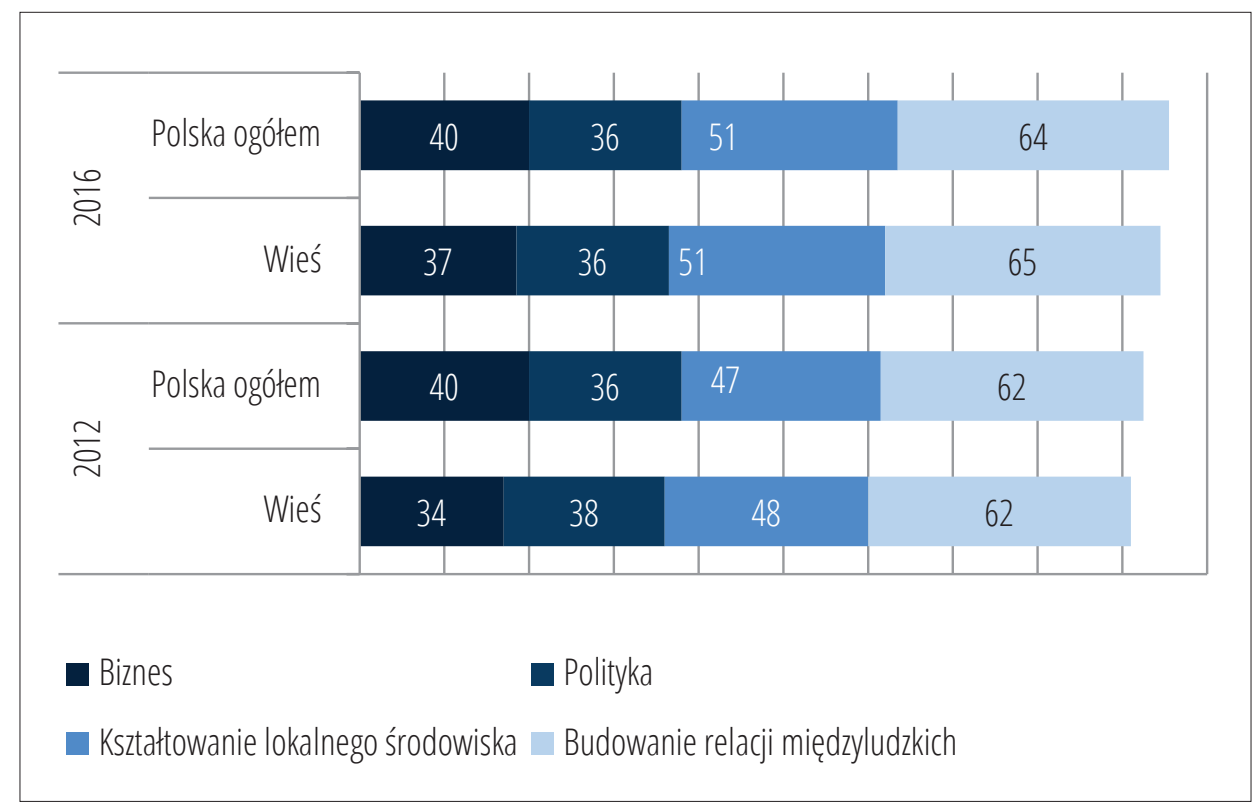

Źródło: Gotowość do współpracy, Komunikat z badań CBOS nr 22/2016; Gotowość Polaków do współpracy w latach 2002-2012, Komunikat z badań CBOS nr BS/19/2012.

Większość badanych rozumie potrzebę współpracy i chce działać wspólnie, ale jak się okazuje ta sama grupa badanych nie ufa innym. Co podkreślają prof. J. Czapiński i prof. T. Panek - autorzy Diagnozy Społecznej - Polska nie spełnia ani jednego kryterium społeczeństwa obywatelskiego. Pod względem ogólnego zaufania zajmujemy jedno z ostatnich miejsc wśród krajów objętych badaniem European Social Survey w 2014 roku. 
Według tych badań w Polsce z opinią, że „większości ludzi można ufać”, zgadzało się zaledwie 10,5 proc. respondentów w latach 2003 i 2005, 11,5 proc. w 2007 roku, 13 proc. w 2009 roku, tyle samo w 2011 roku, 12 proc., w roku 2013 i 15 proc. w 2015 roku - cztery razy mniej niż w Danii, Norwegii i Finlandii ${ }^{27}$. Co warto podkreślić, jeszcze większą nieufność i ostrożność w kontaktach z innymi przejawiają mieszkańcy wsi i rolnicy. W 2016 roku opinię że „Ogólnie biorąc większości ludzi można ufać” podzielało 23\% Polaków, 15\% mieszkańców wsi oraz 18\% rolników. Zdecydowana większość Polaków (74\%), mieszkańców wsi (82\%) oraz rolników (78\%) wybierała opinię „W stosunkach z innymi trzeba być bardzo ostrożnym”. Ogólny, zbiorczy wskaźnik zaufania wśród Polaków jest wciąż na niskim poziomie ${ }^{28}$, co świadczy o wysokim stopniu ostrożności i dużym odsetku osób nieufających innym. Dodatkowo można dostrzec, że wskaźnik ten w 2018 roku nieznacznie się pogorszył, zarówno wśród całej społeczności, jak i mieszkańców wsi (tabela 3.1.).

Tabela 3.1. Ogólny zbiorczy wskaźnik zaufania* w Polsce i na wsi w latach 2016 i 2018

\begin{tabular}{lcc}
\hline Wyszczególnienie & 2016 & 2018 \\
\hline \hline Polska ogółem & $-0,72$ & $-0,89$ \\
\hline Wieś & $-1,06$ & $-1,26$ \\
\hline Rolnicy & $-1,03$ & $-0,90$ \\
\hline
\end{tabular}

* Wskaźnik zaufania przyjmuje wartości od -3 (bardzo duża nieufność, ostrożność) do 3 (bardzo duża ufność, otwartość)

Źródło: Zaufanie społeczne, Komunikat z badań CBOS nr 18/2016; Zaufanie społeczne, Komunikat z badań CBOS nr 35/2018 .

${ }^{27}$ Diagnoza Społeczna 2015, Warunki i jakość życia Polaków - Raport, J. Czapiński, T. Panek (red.), „Contemporary Economics” 2015, t. 9, z. 4, s. 22

${ }^{28}$ Odpowiedzi na kilka pytań: o zaufanie do innych ludzi, zaufanie do nieznajomych spotykanych w różnych życiowych sytuacjach oraz o zaufanie do partnerów w interesach posłużyły autorom komunikatu CBOS do stworzenia syntetycznego wskaźnika zaufania. Wskaźnik ten przyjmuje wartości od -3 (bardzo duża nieufność, ostrożność) do 3 (bardzo duża ufność, otwartość). 
Brak zaufania przekłada się na ostrożne postawy wobec otoczenia. Sprawia, iż ludzie stają się konserwatywni, nadmiernie ostrożni i mało twórczy. Zaufanie natomiast rozwija innowacyjne i prospołeczne postawy, wyzwala aktywność, mobilizuje i przyczynia się do rozwoju społecznego i gospodarczego ${ }^{29}$.

Ciągłe i stosunkowo dynamiczne zmiany w gospodarce rolnej wymuszają wśród mieszkańców wsi zdobywanie i podnoszenie wiedzy i kwalifikacji z zakresu ekonomii i finansów. W badaniu przeprowadzonym przez NBP w 2015 roku „Stan wiedzy i świadomości ekonomicznej Polaków” zarówno subiektywna, jak i obiektywna ocena wiedzy ekonomicznej mieszkańców wsi wypada stosunkowo słabo. Jednakże, co należy podkreślić, odstępstwa te od mieszkańców z miast nie są znaczące (wykresy 3.2. i 3.3.).

Wykres 3.2. Subiektywna ocena wiedzy ekonomicznej Polaków (w \%)

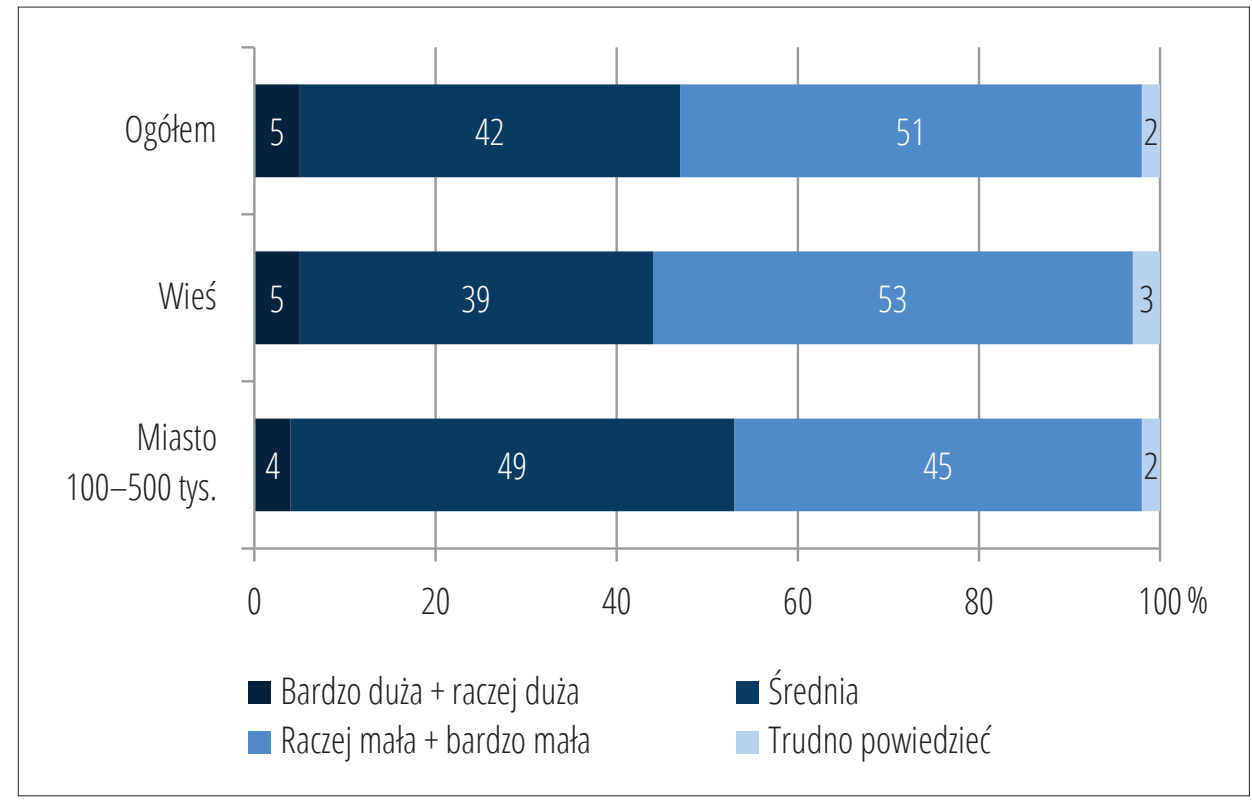

Źródło: Stan wiedzy i świadomości ekonomicznej Polaków, NBP, Warszawa 2015, s. 9.

${ }^{29}$ P. Sztompka, Zaufanie. Fundament społeczeństwa, Wydawnictwo Znak, Kraków 2007. 
Zestawienie subiektywnej jak i obiektywnej oceny wiedzy ekonomicznej pozwala zauważyć, iż grupa ankietowanych mieszkańców wsi w porównaniu z mieszkańcami dużych miast, stosunkowo nisko oceniła swoją wiedzę ekonomiczną. Ostatecznie, wyniki testu ekonomicznego mieszkańców wsi, jak i dużych miast uplasowały się na zbliżonym poziomie. Ta rozbieżność w wynikach może być efektem niższego poczucia własnej wartości i samooceny wśród mieszkańców wsi, co ostatecznie może prowadzić do przejawiania postaw zachowawczych w podejmowaniu przez nich decyzji gospodarczych.

Wykres 3.3. Obiektywna ocena wiedzy ekonomicznej Polaków (w \%)

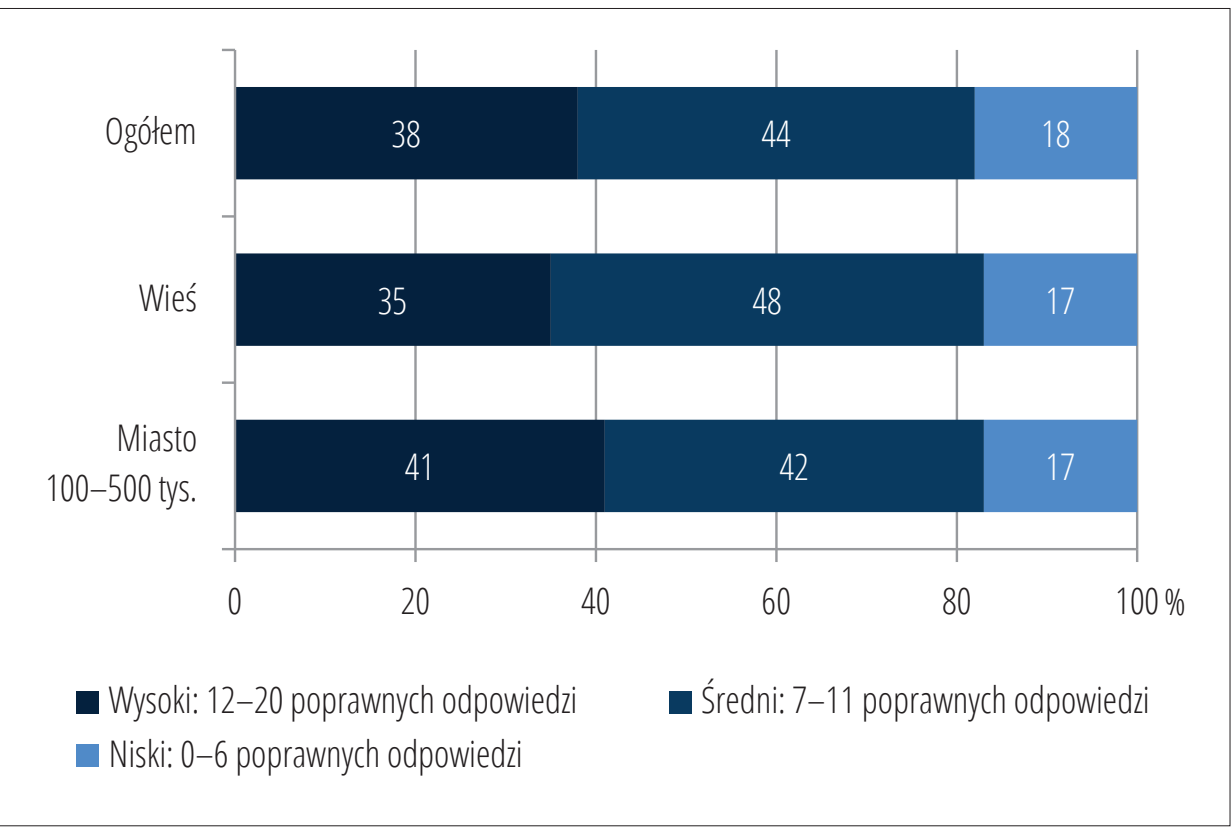

Źródło: Stan wiedzy i świadomości ekonomicznej Polaków, NBP, Warszawa 2015, s. 21.

Kształtowanie wśród mieszkańców wsi postaw przedsiębiorczych wymaga utrwalenia wśród nich pozytywnego wizerunku przedsiębiorcy. Okazuje się, że mieszkańcy wsi posiadają dobrą opinię na temat przedsiębiorców. Według Raportu Polskiej Rady Biznesu na pytanie: „Na ile się Pan/i zgadza lub nie zgadza ze stwierdzeniem dotyczącym wizerunku 
typowego przedsiębiorcy - pożyteczny dla społeczeństwa" 74\% ankietowanych mieszkańców wsi deklaruje pozytywną odpowiedź, podczas gdy w Polsce odsetek ten wynosi $72,6 \%{ }^{30}$. Tym samym pokazuje to, że mieszkańcy wsi są świadomi roli przedsiębiorstw w tworzeniu miejsc pracy, PKB oraz ich wkładu podatkowego w finansowanie państwa.

\section{Podsumowanie}

Przedstawiona analiza wskazuje, że różnice kulturowe między wsią a miastem powoli się zacierają. Wybrane i przeanalizowane elementy kultury ekonomicznej społeczności wiejskich, m.in. gotowość do współpracy, zaufanie, stan wiedzy ekonomicznej nieznacznie różnią się od deklarowanych przez społeczność całego kraju. Mieszkańcy wsi, tak jak pozostali Polacy, wykazują cechy indywidualistów, preferują działania samodzielne, bez uzależnienia od innych. Mimo iż dostrzegają korzyści ze współpracy, to nie są gotowi do jej podejmowania w sferze biznesu, charakteryzują się dużą ostrożnością w kontaktach z innymi i niskim poziomem zaufania. Okazuje się również, że wiedza i świadomość ekonomiczna mieszkańców wsi, również świadomość roli i „pożyteczności” przedsiębiorcy, jest na podobnym poziomie co mieszkańców dużych miast.

Sformułowana na początku badania teza, iż rozwój obszarów wiejskich wymusza zmiany w kulturze ekonomicznej mieszkańców wsi, zdaje się mieć potwierdzenie w zaprezentowanych, wybranych zmiennych określających kulturę ekonomiczną. Zauważa się delikatne zmiany w postawach mieszkańców wsi, a ich kierunek i tempo jest zgodne ze zmianami mającymi miejsce w całym polskim społeczeństwie. Wobec tego rodzi się pytanie, czy zmiany kultury ekonomicznej, w tym postaw prorozwojowych nadążają za dynamicznymi zmianami w gospodarce, również w gospodarce obszarów wiejskich? Czy istnieją sposoby na przyspieszenie tych zmian?

${ }^{30}$ Wizerunek przedsiębiorcy. Raport Polskiej Rady Biznesu 2016, Forum Obywatelskiego Rozwoju, 2016, s. 24. 